\title{
Doktormart, Jual Beli Gelar
}

\author{
Oleh Gede H. Cahyana
}

\section{Opini Koran Pikiran Rakyat, 6 Oktober 2017.}

Rektor Universitas Negeri Jakarta akhirnya diberhentikan menyusul kasus akademik "doktordoktoran”. Lembaga pendidikan yang notabene menghasilkan guru dan beragam ahli di bidang masing-masing itu melakukan tindakan amoral. Apabila program doktor saja seperti itu lantas publik pun bertanya-tanya tentang kualitas program lainnya. Wajarlah ramai diskusi a la warung kopi di kalangan dosen. Pertanyaan serupa pun muncul untuk berbagai kampus di seluruh Indonesia, apakah bebas dari hal serupa itu?

Kasus UNJ bukanlah yang pertama. Sudah pernah merebak malpraktik dalam pengelolaan pendidikan di Jakarta. Belum lagi di kota dan kabupaten di seluruh Indonesia. Dua tahun lalu, ada 243 perguruan tinggi yang ijazahnya tidak diakui untuk tes calon PNS. Kementerian Ristekdikti pun kewalahan karena jumlah perguruan tinggi mencapai 4.500-an unit. Ini seperti kucing-kucingan antara pengawas dan pelaku. Pelaku bukanlah orang awam tetapi orang bergelar doktor, bahkan berjabatan fungsional guru besar dengan sebutan profesor. Lokasinya pun di ibukota, di bawah hidung gedung Kementerian Ristekdikti. Berbagai grup dosen di media sosial Facebook, Twitter, WA membahas kasus tersebut berhari-hari tetapi muaranya hanya gumaman. Tiada tindak dan laku yang bisa diperbuat.

Gelar memang menyilaukan, mulai dari gelar tradisional di berbagai daerah dan suku-bangsa hingga gelar akademik. Beberapa waktu lalu ada juga kasus yang berkaitan dengan gelar akademik tertinggi, yaitu Guru Besar yang dipertanyakan keabsahannya. Padahal di dunia pendidikan sudah jamak dilantunkan peribahasa: sekali lancung ke ujian, seumur hidup orang tak percaya. Tetapi di Indonesia, publik mudah melupakan kesalahan orang sehingga kasus idem ditto terjadi lagi berkali-kali. Dengan alasan ekonomi, orang dengan mudah melupakan sejarah.

\section{Doktormart}

Sebagai jenjang pendidikan tertinggi, program doktor tentu memiliki tingkat kesulitan yang lebih banyak dibandingkan dengan program magister dan sarjana. Penulisan proposal risetnya bisa membutuhkan waktu satu hingga dua semester. Penulisan latar belakang risetnya saja bisa menyerap waktu satu semester atau enam bulan. Jumlah lembar naskah untuk penulisan latar belakang penelitian saja bisa 15 lembar kertas kwarto 1,5 spasi. Hanya latar belakang, belum termasuk maksud, tujuan, metodologi, instrumen, dll. Praproposal pun bahkan ada yang memerlukan studi lapangan, pengambilan sampel data secara langsung.

Lantas, mungkinkah gelar doktor bisa diraih dalam waktu delapan bulan, setahun atau dua tahun? Andaipun ada, ini biasanya berupa kelanjutan dari studi magister sehingga peralatan, data awal, olahan (analisis) sudah tersedia, tinggal dilanjutkan.Belum lama berselang, ada yang 
meraih gelar doktor dalam jangka waktu tiga tahun, dalam usia muda. Jejak studinya terbilang mumpuni. Yang berkualitas di atas rerata saja butuh tiga tahun dan mendekam di laboratorium atau di lapangan atau di depan komputer berbulan-bulan tanpa bisa kerja yang lain. Bagaimana bisa kalangan pekerja, pegawai harian, syahdan pejabat daerah lantas mampu menuntaskan studi doktornya dalam kilasan kilat hujan semusim?

Belum lagi syarat merilis artikel ilmiah di jurnal internasional berakreditasi atau berindeks Scopus misalnya. Ini butuh waktu, bisa setahun. Tentu di luar nalar wajar apabila ada orang yang memperoleh gelar doktor dalam hitungan satu atau dua tahun saja. Yang instan seperti ini hanya bisa terjadi di luar rel akademik dengan azas jual-beli. Tak ubahnya seperti jual-beli di toko sehingga disebut doktormart. Uang bicara kepada dosen, pejabat struktural universitas, promotor dan mahasiswa. Doktormart sungguh merusak dunia akademik Indonesia, melukai perasaan dosen dan mahasiswa yang lurus di jalan kebenaran. Jika tidak ditindak tegas, doktormart akan menyublim menjadi bentuk lain yang sulit diobati, tak terdeteksi pada zaman internet ini.

Selayaknya hukuman diberikan kepada personal yang bersangkut-paut dengan doktormart ini, termasuk pembatalan gelar dan ijazah. Perlu dilakukan juga di jenjang sarjana dan magister agar gelar orang Indonesia sepadan dengan kemampuannya. Jauhkan generasi muda Indonesia menjadi konsumen doktormart, konsumen yang masuk toko, pilih-pilih barang di rak, lalu menuju kasir, bayar, dan "barang gelar" pun dibawa pulang. Jika tidak lekas dibasmi atau dikurangi, maka Indonesia masuk ke relung senja: sandhya kalaning pendidikan. *

Penulis adalah Lektor Kepala Teknik Lingkungan, Universitas Kebangsaan. 